3

\title{
The impact of heat mitigation strategies on the energy balance of a neighborhood in Los Angeles
}

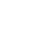

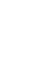

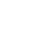

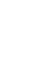

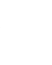

8

\section{Abstract:}

Heat mitigation strategies can reduce excess heat in urban environments. These strategies, including solar reflective cool roofs and pavements, green vegetative roofs, and street vegetation, alter the surface energy balance to reduce absorption of sunlight at the surface and subsequent transfer to the urban atmosphere. The impacts of heat mitigation strategies on meteorology have been investigated in past work at the mesoscale and global scale. For the first time, we focus on the effect of heat mitigation strategies on the surface energy balance at the neighborhood scale. The neighborhood under investigation is El Monte, located in the eastern Los Angeles basin in Southern California. Using a computational fluid dynamics model to simulate micrometeorology at high spatial resolution, we compare the surface energy balance of the neighborhood assuming current land cover to that with neighborhood-wide deployment of green roof, cool roof, additional trees, and cool pavement as the four heat mitigation strategies. Of the four strategies, adoption of cool pavements led to the largest reductions in net radiation (downward positive) due to the direct impact of increasing pavement albedo on ground level solar absorption. Comparing the effect of each heat mitigation strategy shows that adoption of additional trees and cool pavements led to the largest spatial-maximum air temperature reductions at $14: 00 \mathrm{~h}\left(1.0\right.$ and $2.0^{\circ} \mathrm{C}$, respectively). We also investigate how varying the spatial coverage area of heat mitigation strategies affects the neighborhood-scale impacts on meteorology. Air temperature reductions appear linearly related to the spatial extent of heat mitigation strategy adoption at the spatial scales and baseline meteorology investigated here.

\section{Keywords:}

Heat mitigation strategies, energy balance, neighborhood scale, urban heat islands.

\section{Introduction}

The urban heat island (UHI) effect (in the urban canopy layer) is defined as the shelter-height air temperature difference between a city and its rural surroundings. The UHI affects human health

\footnotetext{
${ }^{1}$ Corresponding author's email address: m.taleghani@salford.ac.uk (Mohammad Taleghani) Co-authors' email addresses: peter.crank@asu.edu (Peter Crank); mohegh@usc.edu (Arash Mohegh); dsailor@asu.edu (David J. Sailor); banweiss@usc.edu (George A. Ban-Weiss)
} 
(Kalkstein et al., 2013) and building energy consumption (Akbari and Konopacki, 2005, EPA, 1992, Sailor, 2002) by altering the urban climate. The UHI is stronger at night in cities because heat is stored during the day by thermally massive man-made materials and subsequently released at night after the sun goes down (IPCC, 2001, Moreno-garcia, 1994). Extreme heat is the most prominent weather related cause of mortality in the United States (Davis et al., 2003). Heat-related mortality depends strongly on maximum daytime air temperatures and humidity, but also on elevated air temperature during the night which can limit the human body's ability to release excess heat (Kalkstein et al., 2013). Mortality from this cause significantly increases during heat waves. For instance, in a heat wave during summer 2003 in Europe, 70,000 heat-related deaths were reported (Robine et al., 2008).

One of the main causes of UHIs has to do with the physical properties of urban surfaces. Man-made materials with low albedo (i.e. the fraction of downwelling solar radiation that is reflected by a surface) and high thermal capacity (e.g. asphalt concrete) absorb and store solar radiation in cities more than natural landscapes covered with soil and vegetation. In addition, replacing natural landscapes with manmade materials generally reduces latent heat in favor of sensible heat fluxes. These modifications in the surface energy budget are important contributors to the UHI.

There is body of literature addressing the effect of heat mitigation strategies on building energy (Taleghani et al., 2014b, Taha et al., 1988, Hirano and Fujita, 2012), and neighborhood (Botham-Myint et al., 2015, Taleghani et al., 2014a), urban (Ban-Weiss et al., 2015, Taha, 2008, Vahmani et al., 2016), regional (Sproul et al., 2014, Dev and Surabi, 2011, Santamouris, 2007), and global (Akbari et al., 2009, Zhang et al., 2016) meteorology and climate. Heat mitigation strategies include solar reflective cool roofs and pavements, green vegetative roofs, and street vegetation, all of which alter the land cover to either (a) reduce absorption of sunlight at the surface and subsequent transfer to the atmosphere, or (b) alter re-emission of surface energy in the form of increased latent and decreased sensible heat flux. However, quantification of changes to the surface energy balance at the neighborhood scale is rarely 58 studied.

59 Heat mitigation strategies alter land cover and change the energy balance. The energy balance of the surface can be described as:

$Q^{*}=Q_{H}+Q_{L E}+Q_{G}$ where $Q^{*}$ is net radiation, $Q_{H}$ represents the sensible heat flux, $Q_{\mathrm{LE}}$ describes the latent heat flux, $Q_{\mathrm{G}}$ is the soil heat flux, and all terms are in units of $\mathrm{W} / \mathrm{m}^{2}$ (see Appendix 1 ).

64 Each heat mitigation strategy can affect the surface energy balance in the following ways:

- High albedo cool roofs replacing traditional dark roofs will increase reflected sunlight at roof level and thus decrease net radiation. This decreases the amount of heat available to be released to the atmosphere as sensible heat (and longwave radiation, which is included in net radiation). It also decreases the downward heat flux into the building and may reduce wasteheat emitted by building air conditioning systems.

- High albedo cool pavements replacing traditional dark pavements will increase reflected sunlight at ground level and thus decrease net radiation. This affects the surface energy balance similarly to cool roofs, but occurs at ground level rather than roof level. Thus, in addition to reducing heat that is transferred to the atmosphere, it also can reduce the downward ground 
In this research, we focus on the effect of heat mitigation strategies on the surface energy balance of a neighborhood. Previous studies have mostly investigated the impacts of heat mitigation strategies on either the building scale (i.e. smaller scale than our study) or urban scale (i.e. larger scale than our

heat flux during the day and upward ground heat flux at night. The reflected shortwave radiation may also be intercepted by exterior walls and windows.

- Adding vegetation in the form of green roofs and trees increases evapotranspiration (i.e. the combination of evaporation and transpiration) and reduces sensible heating. In addition, vegetation shades the surface leading to decreases in net radiation of the surface underneath. Any albedo difference between vegetation and the surface that the vegetation replaces can also lead to changes in net radiation. In addition, any soil moisture changes from adopting vegetation and adding irrigation would impact thermal properties soil and thus ground heat fluxes (Vahmani and Ban-Weiss, 2016). study). The neighborhood under investigation is El Monte, located in the eastern Los Angeles basin in Southern California. Using a computational fluid dynamics (CFD) model to simulate micrometeorology at high spatial resolution, we compare the surface energy balance of the neighborhood assuming current land cover to that with widespread deployment of green roof, cool roof, additional trees, and cool pavement as the four heat mitigation strategies. We consider a summer day during a heat wave on the $30^{\text {th }}$ of July 2014 . We also investigate how varying the coverage area of heat mitigation strategies affects the neighborhood-scale impacts on meteorology. Please note that for pedestrian thermal comfort analysis in this neighborhood, readers can refer to our prior study (Taleghani et al., 2016).

\section{Methodology}

Using the CFD model, ENVI-met (Bruse, 2017), we first performed a control simulation of micrometeorology assuming current land cover of the neighborhood. Four perturbation simulations were then carried out, each assuming widespread adoption (over the entire neighborhood) of cool roofs, cool pavements, vegetative roofs, and street level vegetation in the neighborhood. These perturbation simulations were then compared to the baseline to quantify the effect of the mitigation strategies on micrometeorology and the surface energy balance. Subsequent simulations then varied the spatial coverage area of heat mitigation strategies, as will be later discussed.

\subsection{Case study area}

This paper focuses on a neighborhood located in Los Angeles County, in Southern California, USA. Influenced by the Pacific Ocean, this area experiences a Mediterranean climate (Kottek et al., 2006). The neighborhood contains a financially vulnerable population (Figure 1) with annual income that is $\$ 10967$ lower than the annual average in the US (United States Census Bureau, 2010). Sixty-five percent of the people in the area are below the California adjusted poverty threshold (twice the national threshold), placing it in the poorest $20 \%$ of neighborhoods in the county (CalEnviroScreen, 2014). The neighborhood has a tree coverage fraction of 0.062 , which is lower than $85 \%$ of the neighborhoods in Los Angeles County. The combination of these factors makes the selected neighborhood vulnerable to heatwaves. The study domain covers $650 \mathrm{~m} * 450 \mathrm{~m}$, and represents a residential neighborhood (Figure 1). Most of 
114 the buildings have two stories with grass covered yards. The roads and sidewalks are covered with 115 asphalt concrete and cement concrete, respectively.

116
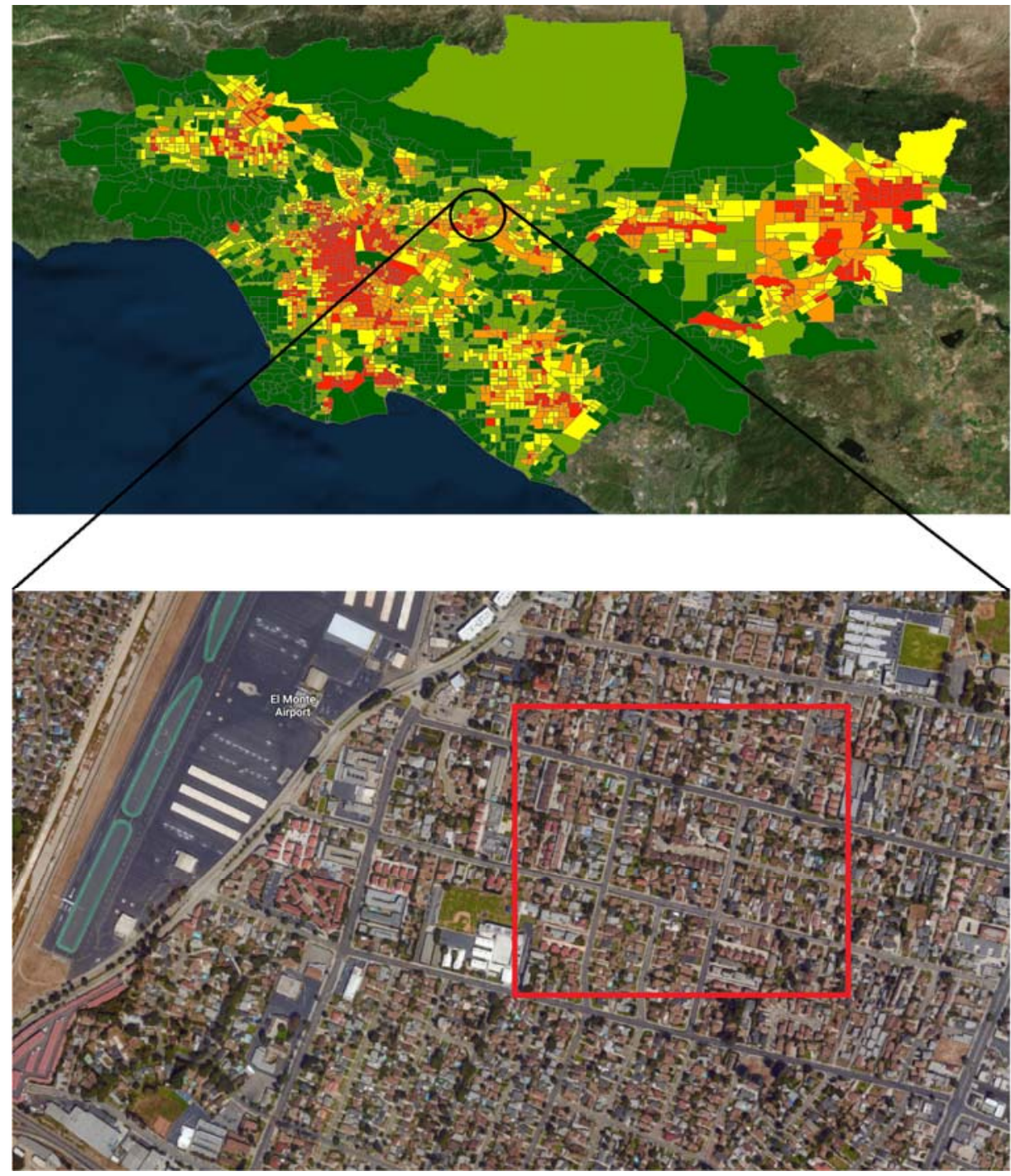

\section{Poverty}

$0-17 \%$ (1st quantile) 17 - 30\% (2nd quantile) $30-44 \%$ (3rd quantile) $44-59 \%$ (4th quantile) $59-100 \%$ (5th quantile)

Figure 1: Top: The location of El Monte in Los Angeles County. The map shows the poverty level of neighborhoods 
123 In this research we use a high-resolution computational fluid dynamics model, ENVI-met (Bruse, 2017).

124 It numerically solves the Reynolds Average Navier-Stokes (RANS) equations. With ENVI-met, it is possible 125 to simulate interactions between the surface (both manmade and natural) and air (Bruse and Fleer,

Simulations in ENVI-met are based on data provided within two files:

- The input file describes the physical environment such as trees and buildings, the surface characteristics such as roof and pavements, and the geographical location of the model.

- The configuration file determines the initial and boundary conditions of the simulation such as wind speed and air temperature. The duration of the simulation, heat transmission of building surfaces, and albedo of urban surfaces are also specified here.

The simulations start at 4:00h (local time) on 30 July 2014 and run for a period of 24 hours. The spatial resolution is $3 \mathrm{~m} \times 3 \mathrm{~m} \times 1 \mathrm{~m}(\mathrm{dx}, \mathrm{dy}, \mathrm{dz})$. The initial $2 \mathrm{~m}$ air temperature in the domain is $19.4{ }^{\circ} \mathrm{C}$. The initial wind speed in the first $10 \mathrm{~m}$ above the ground is $1.6 \mathrm{~m} / \mathrm{s}$ and westerly $\left(270^{\circ}\right)$. The relative humidity is $81 \%$. Finally, the albedo of the walls, roofs and pavements are $0.2,0.1$ and 0.2 , respectively, and heat transmissions of $0.31 \mathrm{~W} / \mathrm{m}^{2} \mathrm{~K}$ (walls) and $0.33 \mathrm{~W} / \mathrm{m}^{2} \mathrm{~K}$ (roof) are used. The internal building temperature is assumed to be $293 \mathrm{~K}\left(=20^{\circ} \mathrm{C}\right)$.

The boundary condition and wind profile options were left as defaults. The lateral boundary condition (LBC) was set to "open". The LBC helps inform and stabilize the model as temperature, wind, and humidity change near the edge of the domain during the simulation. The open LBC takes the temperature, wind, and humidity values of grid points near the edge of the domain and copies them into the border grid points for each time step within the simulation. This reduces the effect of the boundary on the domain, though may not be the most realistic approach for model validation, and may not necessarily improve the stability of the model (Bruse, 2017). Overall, the approach to handling boundary conditions remains constant throughout the simulation. The wind profile is set to a relatively stable profile. Winds at the surface are set to $\sim 1 \mathrm{~m} / \mathrm{s}$ at the lowest levels of the domain, increasing to 3.5 $\mathrm{m} / \mathrm{s}$ at the top of the domain. Overall, the wind profile does lead to high amounts of advection into and out of the domain. But assuming the wind profile has no impact on the energy transfer by advection allows for a simpler resolution of the energy balance for the entire volume. This simplification allows for greater attention to detail in the model to be given to the anthropogenic, incoming/outgoing solar radiation, and turbulent heat flux (latent and sensible) terms of the energy balance. 
162 In the control simulation (CO), micrometeorology assuming the current land cover of the neighborhood 163 is modeled for the $24^{\text {th }}$ of July 2014. There was a heat wave on this day over the Southwest US (see 164 Appendix 2). The current land cover was obtained from Google Earth and the street views of Google Maps. Four perturbation simulations were carried out based on the control model with the following changes:

- The green roof scenario (GR) added grass (and a root zone) to the building roofs.

- The cool roof scenario (CR) increased the albedo of the building roofs from 0.1 to 0.4 .

- The trees added scenario (TA) added street trees on grasses in canyons.

- The cool pavement scenario (CP) increased the albedo of the roadway from 0.2 to 0.5 . For more details see our companion paper (Taleghani et al., 2016).

\section{Results}

\subsection{Air and ground surface temperatures in the control simulation}

Figure 2 illustrates the surface air temperature at $1.5 \mathrm{~m}$ above the ground and the ground surface temperature for the neighborhood at 14:00h. The highest surface air temperature in the neighborhood is $29.4{ }^{\circ} \mathrm{C}$, located above asphalt concrete pavement (Figure 2a). The coolest surface air temperatures are associated with vegetated areas between the residential buildings $\left(26.1^{\circ} \mathrm{C}\right)$. This indicates that the local land cover has a significant role on the local air temperature, in accordance with other studies (Hart and Sailor, 2009, Santamouris, 2014, Taleghani et al., 2014d) that show that land surface characteristics alter the microclimate. Similarly, surface temperatures are highest for pavements $\left(44^{\circ} \mathrm{C}\right)$, while grasses have the lowest surface temperatures $\left(24.7^{\circ} \mathrm{C}\right.$ ) (Figure $2 \mathrm{~b}$ ).

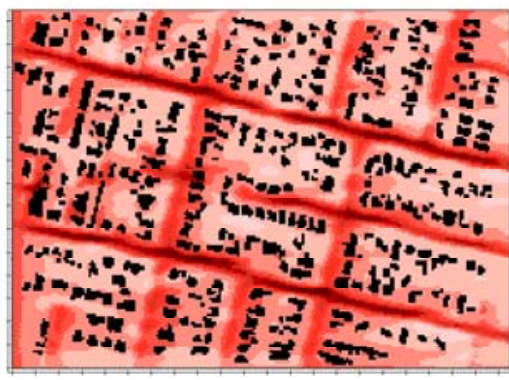

a)

Air Temperature

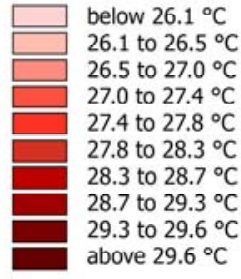

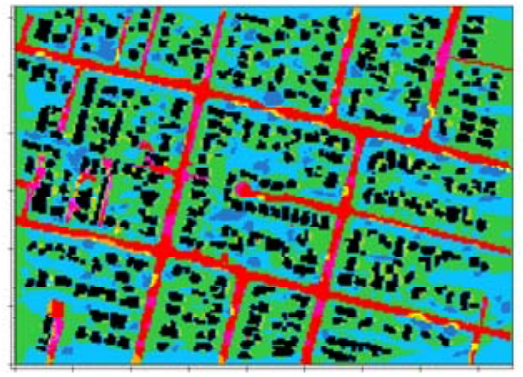

b)

Surface Temperature

below $23.1^{\circ} \mathrm{C}$ 23.1 to $26.3^{\circ} \mathrm{C}$ 26.3 to $29.6^{\circ} \mathrm{C}$ 29.6 to $32.8^{\circ} \mathrm{C}$ 32.8 to $36.0^{\circ} \mathrm{C}$ 36.0 to $39.3^{\circ} \mathrm{C}$ 39.3 to $42.5^{\circ} \mathrm{C}$ 42.5 to $45.7^{\circ} \mathrm{C}$ 45.7 to $49.0^{\circ} \mathrm{C}$ above $49.0^{\circ} \mathrm{C}$

Figure 2: Maps of (a) air temperature at a height of $1.5 \mathrm{~m}$, and (b) ground surface temperature $(\mathrm{z}=0 \mathrm{~m})$, both at 14:00h on 30 July 2014 . 
191 Figure 3 shows the impacts of adopting heat mitigation strategies relative to the control on various

192 meteorological variables including surface air temperatures, surface temperatures, net radiation, 193 sensible heat flux, latent heat flux, and soil heat flux, at 14:00h.

194 Comparing the changes in surface air temperatures among the different scenarios relative to the control, adopting cool pavements led to the most cooling, up to $2.0^{\circ} \mathrm{C}$. The TA scenario also reduced surface air temperature up to $1.0^{\circ} \mathrm{C}$ in the canyons where new trees were added. The $\mathrm{CR}$ and $\mathrm{GR}$ scenarios reduced surface air temperatures in the neighborhood less than TA and CP. This is because these scenarios changed the building roof characteristics, which are mostly at the height of $6 \mathrm{~m}$. Thus, at the neighborhood scale, this model suggests that roof surface properties are not as tightly coupled to near-ground air temperatures. More coupling could occur under conditions that promote enhanced vertical mixing.

Comparing changes in ground surface temperatures among the different scenarios, the CP scenario shows the maximum reduction of up to $6.9^{\circ} \mathrm{C}$. In the TA scenario, ground surface cooling occurs throughout the neighborhood but especially where new trees are added in the canyons. The CR and GR scenarios did not affect surface temperatures as much as the other two scenarios, as expected.

Figure 3 also shows the absolute differences in net radiation (downward positive) for perturbation scenarios compared to the control. The adoption of cool pavements markedly reduces net radiation up to $320 \mathrm{~W} / \mathrm{m}^{2}$. The TA scenario also leads to reductions in net radiation in locations where new trees are added by up to $246 \mathrm{~W} / \mathrm{m}^{2}$. While the albedo of grass and trees are the same in this model $(0.2)$, the reduction in net radiation occurs due to the trees shading the ground. The GR and CR scenarios did not change surface net radiation relative to the control as expected.

Heat mitigation strategies had differing effects on sensible heat fluxes (upward positive) in the neighborhood. The CP scenario shows the maximum reduction in sensible heat flux of up to $257 \mathrm{~W} / \mathrm{m}^{2}$ over pavements that were converted from low albedo to solar reflective. This occurs as increasing the albedo of the ground reduces net radiation, and thus the energy available to be re-emitted as convective heat to the atmosphere. The TA scenario reduced the sensible heat flux where new trees were added. This is similar to the mechanism for cool pavements but is driven by the impacts of shading the ground on net radiation. CR and GR did not appreciably change the sensible heat flux at the ground.

As the latent heat flux (upward positive) is associated with evapotranspiration of water at the surface, the TA scenario caused the maximum reduction of up to $212 \mathrm{~W} / \mathrm{m}^{2}$ beneath newly added trees. The other scenarios showed markedly lower changes in latent heat flux as expected. Reductions in latent heat flux in the CP scenario may be from decreases in surface heating leading to reductions in buoyancy and thus vertical mixing of water vapor. This would lead to reductions in water vapor differential, which would be expected to reduce evaporative fluxes.

Soil heat flux reductions (downward positive) are largest in the CP scenario, up to $65 \mathrm{~W} / \mathrm{m}^{2}$ over newly adopted cool pavements. This is consistent with the large reductions in surface temperature and net radiation in this scenario. Soil heat flux is also reduced in TA under newly added trees, but to a lesser extent than in CP. The roof level modifications (CR and GR) did not appreciably change soil heat flux. 

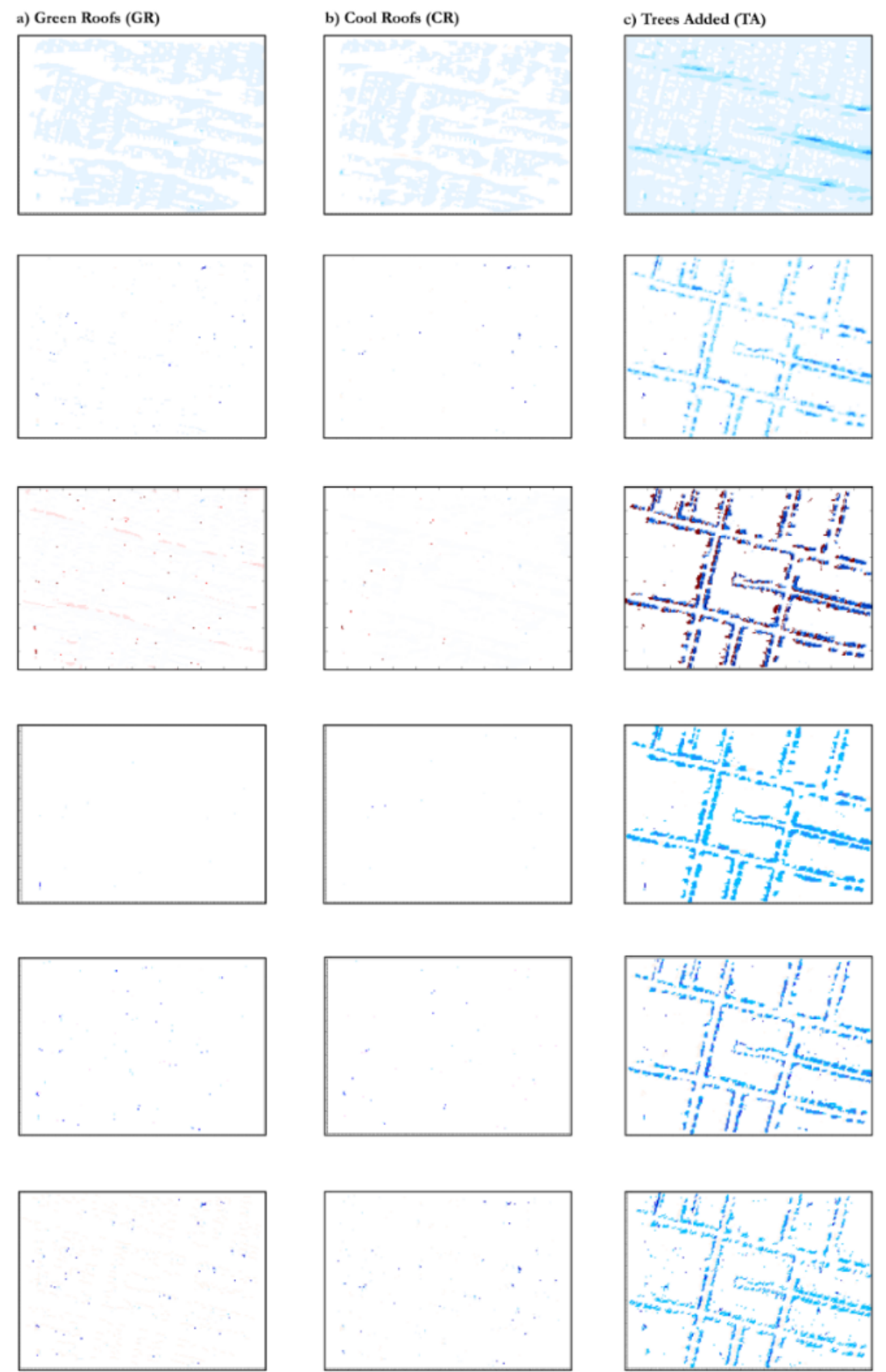
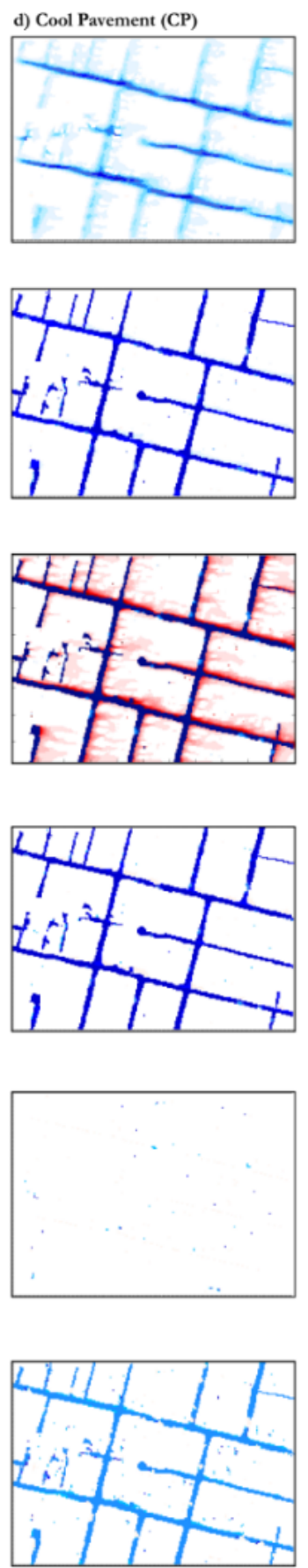

Surface Air Temperature Difference (K)

below $-1.7 \mathrm{~K}$ -1.7 to $-1.5 \mathrm{~K}$ -1.5 to $-1.3 \mathrm{~K}$ -1.3 to $-1.1 \mathrm{~K}$ -11 to $-0.8 \mathrm{~K}$ $-0.850-0.6 \mathrm{~K}$ $-0.86-0.6 \mathrm{~K}$ -0.6 to $-0.4 \mathrm{~K}$ -0.4 to $-0.2 \mathrm{~K}$ -0.2 to $0.1 \mathrm{~K}$ above $0.1 \mathrm{~K}$

Surface Temperature Difference (K)

below $-6.8 \mathrm{~K}$ below $-6.8 \mathrm{~K}$
-6.8 to $-5.9 \mathrm{~K}$ 5.9 to $-5.0 \mathrm{~K}$ -5.0 to $-4.1 \mathrm{~K}$ 4.1 to $-3.2 \mathrm{~K}$ -3.2 to $-2.3 \mathrm{~K}$ -2.3 to $-1.4 \mathrm{~K}$ -1.4 to $-0.5 \mathrm{~K}$ -0.5 to $0.4 \mathrm{~K}$ -0.5 to $0.4 \mathrm{~K}$

Net Radiation Difference (W/m2) $+2$

.50 $-100$ .150

$-200$

Sonsible Heat Flux Difference $\left(W / m^{2}\right)$

below $-225.0 \mathrm{~W} / \mathrm{m}^{2}$

below $-225.0 \mathrm{~W} / \mathrm{m}^{2}$ -195.0 to $-165.0 \mathrm{~W} / \mathrm{m}^{2}$ -195.0 to $-165.0 \mathrm{~W} / \mathrm{m}^{2}$ -165.0 to $-135.0 \mathrm{~W} / \mathrm{m}^{2}$ -135.0 to $-105.0 \mathrm{~W} / \mathrm{m}^{2}$ -105.0 to $-75.0 \mathrm{~W} / \mathrm{m}^{2}$ -75.0 to $-45.0 \mathrm{~W} / \mathrm{m}^{2}$ -45.0 to $-15.0 \mathrm{~W} / \mathrm{m}^{2}$ -15.0 to $15.0 \mathrm{~W} / \mathrm{m}^{2}$ above $15.0 \mathrm{~W} / \mathrm{m}^{2}$

Latent Heat Flux below $190.0 \mathrm{~W} / \mathrm{m}^{2}$ -1650 to $-140.0 \mathrm{~W} / \mathrm{m}^{2}$ -165.0 to $-140.0 \mathrm{~W} / \mathrm{m}^{2}$ -140.0 to $-115.0 \mathrm{~W} / \mathrm{m}^{2}$ -115.0 to $-90.0 \mathrm{~W} / \mathrm{m}^{2}$ -90.0 to $-65.0 \mathrm{~W} / \mathrm{m}^{2}$ -65.0 to $-40.0 \mathrm{~W} / \mathrm{m}^{2}$ -40.0 to $-15.0 \mathrm{~W} / \mathrm{m}^{2}$ -15.0 to $10.0 \mathrm{~W} / \mathrm{m}^{2}$ above $10.0 \mathrm{~W} / \mathrm{m}^{2}$

Soil Heat Flux Difference $(W / m 2)$

\section{below $-60.0 \mathrm{~W} / \mathrm{m}^{2}$} below $-60.0 \mathrm{~W} / \mathrm{m}^{2}$ -60.0 to $-52.0 \mathrm{~W} / \mathrm{m}^{2}$ -52.0 to $-44.0 \mathrm{~W} / \mathrm{m}^{2}$ -44.0 to $-36.0 \mathrm{~W} / \mathrm{m}^{2}$ -36.0 to $-28.0 \mathrm{~W} / \mathrm{m}^{2}$ -28.0 to $-20.0 \mathrm{~W} / \mathrm{m}^{2}$ -20.0 to $-12.0 \mathrm{~W} / \mathrm{m}^{2}$ -12.0 to $-4.0 \mathrm{~W} / \mathrm{m}^{2}$ -4.0 to $4.0 \mathrm{~W} / \mathrm{m}^{2}$ above $4.0 \mathrm{~W} / \mathrm{m}^{2}$

Figure 3: Absolute differences in micrometeorological variables between various heat mitigation scenarios and the control simulation at 14:00. Note that absolute differences of surface air 
Figure 4 presents hourly mean diurnal profiles of changes in surface energy budget variables. Values represent the spatial mean values for outdoor grid cells in the domain.

The cool pavement scenario reduced surface net radiation (Figure 4a) in the neighborhood more than the other heat mitigation scenarios, with maximum reduction of $47.1 \mathrm{~W} / \mathrm{m}^{2}$ at $12: 00 \mathrm{~h}$. As the sun is the driver of the surface energy balance (Oke, 2002), net radiation reductions largely occurred between 6:00 and 18:00. The TA scenario also reduced net radiation during the day with maximum of $23.2 \mathrm{~W} / \mathrm{m}^{2}$. However, consistent with Figure 3, the CR and GR scenarios minimally affect the surface energy balance 243 at the ground.

Reductions in net radiation led to decreases in sensible heat flux (Figure 4b) during the day for the cool pavement scenario. Decreases in sensible heating during the day were larger for this scenario than the other three heat mitigation strategies. The maximum reduction is $36 \mathrm{~W} / \mathrm{m}^{2}$ occurring at $13: 00 \mathrm{~h}$. For the TA scenario, the largest reductions occur between 13:00 and 17:00, with maximum reduction reaching $9.4 \mathrm{~W} / \mathrm{m}^{2}$ at $15: 00 \mathrm{~h}$. In general, adding vegetation reduces the Bowen ratio, which is the ratio of sensible to latent heat flux. Thus, even for constant net radiation, adding trees would be expected to lead to the repartitioning of surface energy in favor of lower ratios of sensible heat to latent heat flux. The $C R$ and GR scenarios lead to small changes in sensible heat flux throughout the day.

Reductions in latent heat flux (Figure 4c) are largest for the TA scenario. The maximum reduction, which occurs at $11: 00 \mathrm{~h}$, is $16.1 \mathrm{~W} / \mathrm{m}^{2}$. We originally hypothesized that TA should lead to increases in latent heat fluxes. The decreases in latent heat fluxes modeled here could have been caused by decreases in soil evaporation (caused by shading the surface) being larger than increases in leaf evaporation and transpiration. This type of model behavior has been observed by larger scale land models in previous research (Pitman et al., 2009). The other scenarios did not appreciably affect latent heat fluxes at the 258 surface.

259 Reductions in net radiation led to decreases in ground heat flux (downward positive) (Figure 4d) in the CP scenario during sunlit hours. The maximum reduction was $12.5 \mathrm{~W} / \mathrm{m}^{2}$ at 9:00 am. The diurnal cycle of changes in ground heat flux was different for the TA scenario than for CP in that two local maxima occur at 7:00 $\left(5.4 \mathrm{~W} / \mathrm{m}^{2}\right)$ and $16: 00\left(3.3 \mathrm{~W} / \mathrm{m}^{2}\right)$. We hypothesize that this is mainly because of the shading effect of trees, where shading is at a minimum at noon and a maximum when the solar elevation is lower. Thus, even though the solar intensity at the surface is largest at noon, the impact of shading on spatial averages leads to maximum soil heat fluxes in the morning and afternoon. Changes in ground heat fluxes are positive at night, meaning that upward heat fluxes are decreased. This behavior was seen in a previous study on cool pavements (Mohegh et al., 2017). 

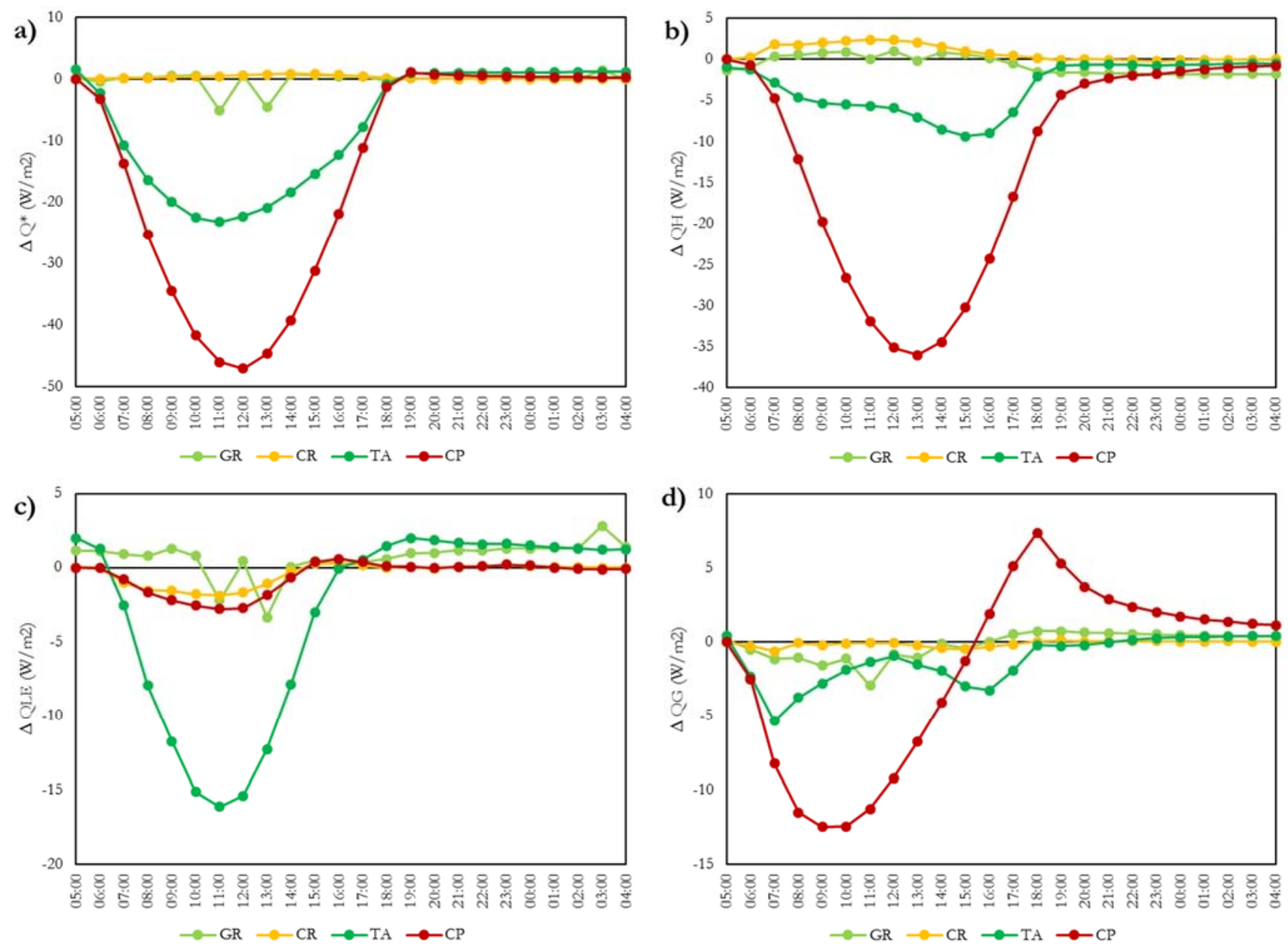

Figure 4: Hourly mean diurnal profiles of net radiation $\left(\Delta Q^{*}\right)$, sensible heat flux $\left(\Delta Q_{H}\right)$, latent heat flux $\left(\Delta \mathrm{Q}_{\mathrm{LE}}\right)$, and soil heat flux $\left(\Delta \mathrm{Q}_{\mathrm{G}}\right)$. Values are shown for each heat mitigation scenario relative to the control simulation.

\subsection{Sensitivity of neighborhood scale air temperature on the spatial extent of heat mitigation} adoption

The cool pavement (CP) and trees added (TA) scenarios led to the largest changes in neighborhood-scale surface air temperatures among the four heat mitigation strategies investigated here. It is of interest to assess how air temperature changes respond to different spatial extents of heat mitigation adoption. To investigate this issue, we carried out further simulations that implement cool pavements and added 280 trees as follows:

281 Area 1: Only the street at the center of the modeling domain,

282 Area 2: The central block at the center of the modeling domain, and

Area 3: The entire neighborhood. 
Figure 5 demonstrates the absolute difference in surface air temperature at 14:00h after adopting added trees or cool pavements in the three areas relative to the control simulation. For TA in area 1, a small temperature reduction is evident on the street with added trees. The mean temperature reduction in area 1 is $0.1{ }^{\circ} \mathrm{C}$, while the neighborhood average temperature reduction is $0.01{ }^{\circ} \mathrm{C}$. When added to area 2, temperature reductions occur on the east-west streets, while north-south streets have minimal temperature reduction. This likely occurs because of the westerly winds in the domain; temperature reductions accumulate as air is advected toward the east. The mean neighborhood temperature reduction in area 2 is $0.1{ }^{\circ} \mathrm{C}$, while that for the neighborhood is $0.05^{\circ} \mathrm{C}$. When added to area 3 , the TA scenario leads to the largest neighborhood-scale air temperature reductions, with a mean temperature reduction of $0.2^{\circ} \mathrm{C}$. Again, temperature changes are largest for east-west streets.

Cool pavement adoption led to larger air temperature reductions in each area than added trees. Even when added only to area 1 , temperature reductions in area 1 were $0.2^{\circ} \mathrm{C}$, while the corresponding neighborhood average reduction was $0.01^{\circ} \mathrm{C}$. When added to area 2, cool pavements reduced average temperatures in area 2 by $0.2{ }^{\circ} \mathrm{C}$, and neighborhood average temperature by $0.08{ }^{\circ} \mathrm{C}$. Adding cool pavements to area 3 led to the largest neighborhood mean temperature reduction of $0.26{ }^{\circ} \mathrm{C}$. For cool pavement adoption in area 1 and 2, it can be seen that temperature reductions are advected eastward 300 for roughly 72 and $75 \mathrm{~m}$, respectively.
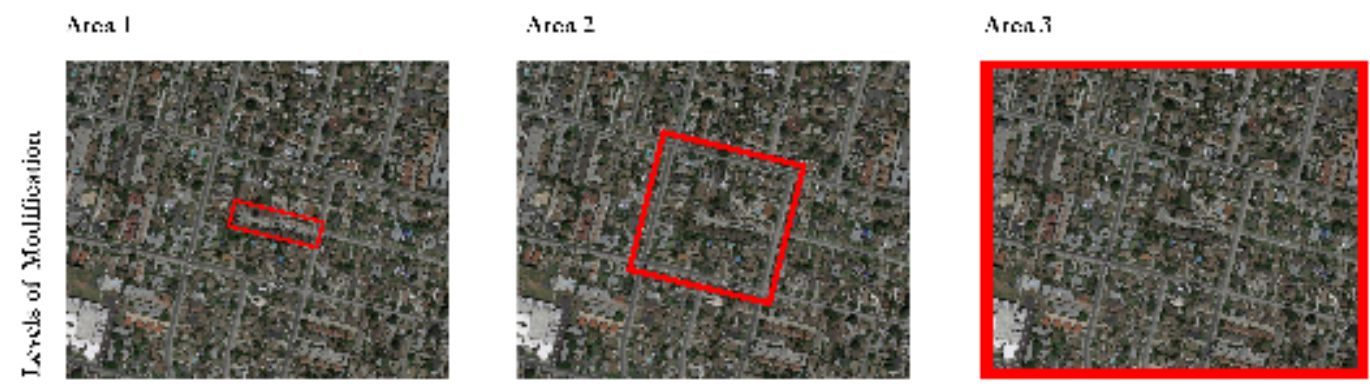

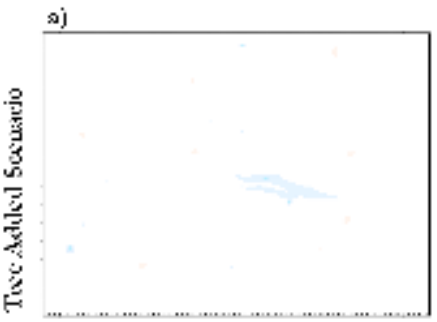

d)

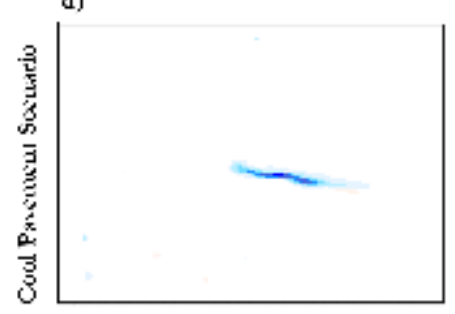

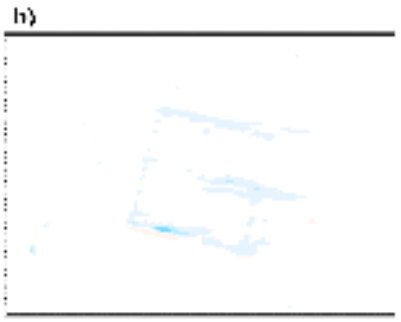

c)

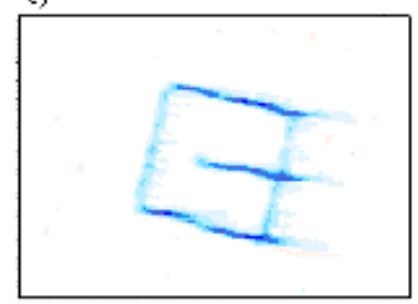

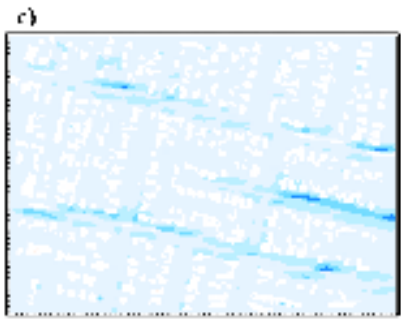

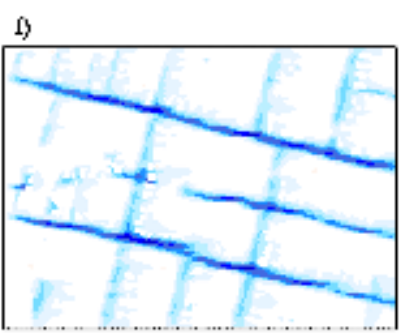

Lir Temperature: I)ifference (K)

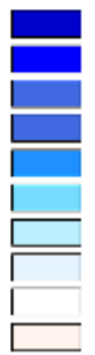

below $-1.7 \mathrm{~K}$ -1.7 t $1.5 \mathrm{~K}$ $-1.5 m-1.3 k$ -1.3 to - $1.1 \mathrm{~K}$ -1.1 to - D.8 K -0.8 to $-0.6 \mathrm{~K}$ -0.6 to $-0.4 \mathrm{~K}$ -0.4 to $-0.2 \mathrm{~K}$ -0.2 t $0.1 \mathrm{~K}$ above $0.1 \mathrm{~K}$

Figure 5: Surface air temperature difference at 14:00h compared to the control model when trees (a to c) and cool pavements ( $d$ to f) are added to areas 1, 2, and 3 (shown in the top row). 
304 Table 1 shows the number of $3 \times 3 \mathrm{~m}$ cells that are modified in each scenario, the temperature 305 reductions for a receptor point at the center of the neighborhood (over pavement), temperature 306 reductions averaged over areas 1,2 , or 3 (depending on scenario), and temperature reductions 307 averaged over the entire neighborhood.

308 In general, air temperature reductions at the center of the neighborhood increase as the spatial extent 309 of adding trees and cool pavements increases (Table $1,2^{\text {nd }}$ column). While adding trees to area 1 has no 310 effect on the temperature at the center of the neighborhood, adding trees to area 2 and 3 have similar 311 temperature change per area modified. For $\mathrm{CP}$, modifying area 1 has a much larger impact on

312 temperature change per area modified than that of area 2 and 3 (Table $1,5^{\text {th }}$ column). This suggests that 313 the air temperature impacts on a given street of cool pavement adoption are dominated by that street, 314 and not cool pavement adoption on other streets, at least when considering the micrometeorological 315 scale.

316 For both the TA and CP scenarios, neighborhood average temperature reductions are larger when the 317 spatial extent of the heat mitigation strategy increases (Table $1,4^{\text {th }}$ column). For both CP and TA, this 318 temperature change is roughly constant, however, when normalized per area modified (Table $1,7^{\text {th }}$ 319 column). In other words, air temperature reductions appear linearly related to the spatial extent of heat 320 mitigation strategy adoption at the spatial scales and baseline meteorology investigated here. 
Table 1: The air temperature reductions in different areas (as illustrated in Figure 5).

\begin{tabular}{|c|c|c|c|c|c|c|c|}
\hline & $\begin{array}{l}\text { Modified } \\
\text { cells }\end{array}$ & $\begin{array}{l}\text { Temperature } \\
\text { reduction at } \\
\text { the center of } \\
\text { the } \\
\text { neighborhood } \\
\left({ }^{\circ} \mathrm{C}\right)\end{array}$ & $\begin{array}{l}\text { Mean } \\
\text { temperature } \\
\text { reduction } \\
\text { averaged over } \\
\text { area } \\
\text { corresponding } \\
\text { to scenario } \\
\text { (i.e. Area } 1,2 \text {, } \\
\text { or } 3)\left({ }^{\circ} \mathrm{C}\right)\end{array}$ & $\begin{array}{l}\text { Mean } \\
\text { temperature } \\
\text { reduction } \\
\text { averaged } \\
\text { over the } \\
\text { entire } \\
\text { neighborhood } \\
\left({ }^{\circ} \mathrm{C}\right)\end{array}$ & $\begin{array}{l}\text { Temperature } \\
\text { reduction at } \\
\text { the center of } \\
\text { the } \\
\text { neighborhood } \\
\text { per modified } \\
\text { area }\left({ }^{\circ} \mathrm{C} \mathrm{m}^{-2}\right. \\
\times 100,000)\end{array}$ & $\begin{array}{l}\text { Mean } \\
\text { temperature } \\
\text { reduction } \\
\text { averaged over } \\
\text { area } \\
\text { corresponding } \\
\text { to scenario } \\
\text { per modified } \\
\text { area }\left({ }^{\circ} \mathrm{C} \mathrm{m}^{-2} \mathrm{x}\right. \\
100,000)\end{array}$ & $\begin{array}{l}\text { Mean } \\
\text { temperature } \\
\text { reduction } \\
\text { averaged } \\
\text { over the } \\
\text { entire } \\
\text { neighborhood } \\
\text { per modified } \\
\text { area }\left({ }^{\circ} \mathrm{C} \mathrm{m}^{-2} \mathrm{x}\right. \\
100,000)\end{array}$ \\
\hline \multirow{3}{*}{ 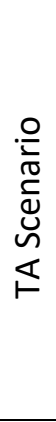 } & $\begin{array}{l}\text { Area } 1 \\
(111 \\
\text { cells) }\end{array}$ & 0 & 0.1 & 0.01 & 0 & 10.0 & 1.0 \\
\hline & $\begin{array}{l}\text { Area } 2 \\
(466 \\
\text { cells) }\end{array}$ & 0.04 & 0.1 & 0.05 & 1.0 & 2.4 & 1.2 \\
\hline & $\begin{array}{l}\text { Area } 3 \\
(2562 \\
\text { cells) }\end{array}$ & 0.21 & 0.2 & 0.22 & 0.9 & 0.9 & 1.0 \\
\hline \multirow{3}{*}{ 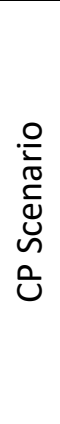 } & $\begin{array}{l}\text { Area } 1 \\
(157 \\
\text { cells) }\end{array}$ & 0.51 & 0.2 & 0.01 & 36.1 & 14.2 & 0.7 \\
\hline & $\begin{array}{l}\text { Area } 2 \\
(1286 \\
\text { cells) }\end{array}$ & 0.55 & 0.2 & 0.08 & 4.8 & 1.7 & 0.7 \\
\hline & $\begin{array}{l}\text { Area } 3 \\
\text { (4427 } \\
\text { cells) }\end{array}$ & 0.56 & 0.26 & 0.26 & 1.4 & 0.7 & 0.7 \\
\hline
\end{tabular}




\section{Conclusions}

This paper has investigated the effects of four heat mitigation strategies on temperatures and the surface energy balance of a neighborhood in the eastern Los Angeles basin. Micrometeorological simulations were performed with ENVI-met for a summer day during a heat wave in July 2014. First, the microclimate of the neighborhood under investigation was simulated and analyzed assuming current land cover. Next the microclimate of the neighborhood was simulated assuming adoption of solar reflective cool roofs, green vegetative roofs, additional street trees, and cool pavements.

We show that cool pavements reduce net radiation at the surface more than the other heat mitigation strategies. Adding street trees reduces net radiation as well by shading the surface. Reductions in net radiation cause cool pavements to reduce the surface sensible heat flux up to $320 \mathrm{~W} / \mathrm{m}^{2}$. Adding trees reduces sensible heat flux to a lesser extent than cool pavements. Adding trees also lead to the largest reductions in latent heat flux among the scenarios. While adding trees may have been expected to increase latent heat flux, the modeled decrease is likely from shading the surface leading to decreased energy available for soil evaporation. Using green and cool roofs did not significantly change the energy balance of the ground surface as they were implemented at the height of 6 meters (on two story buildings). Both spatial variations and diurnal cycles in the surface energy balance are investigated.

We also investigated the sensitivity of neighborhood scale air temperature on the spatial extent of heat mitigation adoption for adding trees and cool pavements. We simulated adoption of these strategies in three areas, from the center street of the domain to the entire neighborhood. We found that increasing the spatial extent of adopting trees and cool pavements generally led to larger reductions in surface air temperature, both at the center of the neighborhood (over pavement), and averaged over the entire neighborhood. When normalized per area modified, temperature reductions are mostly independent of the spatial extent of cool pavement adoption or tree addition. In other words, air temperature reductions appear linearly related to the spatial extent of heat mitigation strategy adoption at the spatial scales and baseline meteorology investigated here. Analogous linearity has been reported in studies using mesoscale climate models (Mohegh et al., 2017, Dan et al., 2014). Further research should try to harmonize predicted temperature reductions from heat mitigation strategies ranging from neighborhood to urban scales.

\section{Acknowledgments}

This research was funded by the National Science Foundation under grants CBET-1512429, and CBET1623948. It was also funded in part by the Rose Hills Foundation and the USC Provost's Office. 


\section{Appendices}

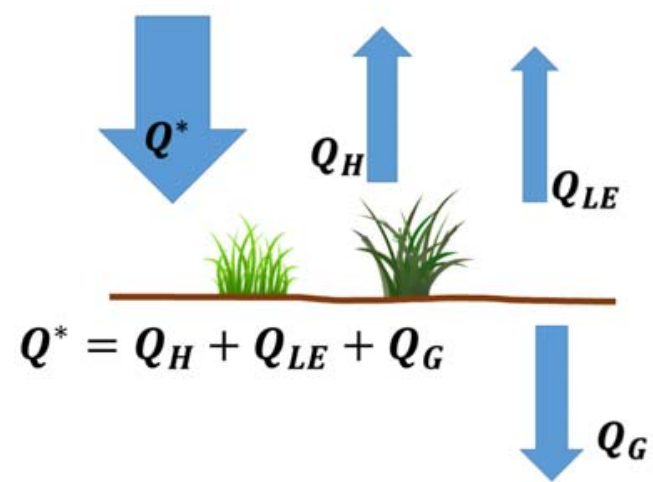

Appendix 1: Fluxes involved in the surface energy balance.

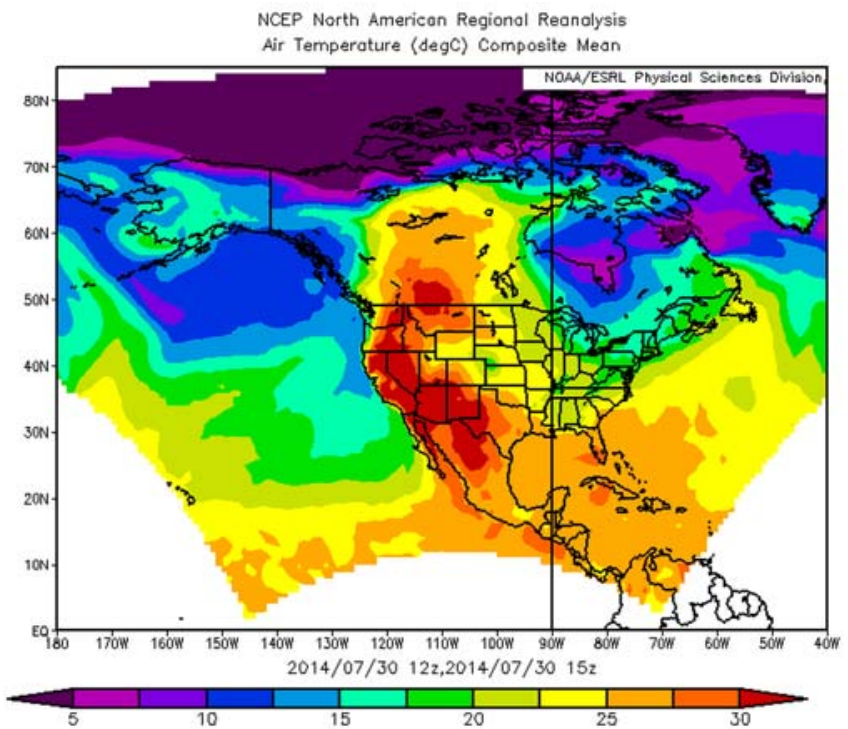

Appendix 2: Air temperature in North America on $24^{\text {th }}$ of July 2014 (retrieved from (NOAA, 2015)). 


\section{References}

AKBARI, H. \& KONOPACKI, S. 2005. Calculating energy-saving potentials of heat-island reduction strategies. Energy Policy, 33, 721-756.

AKBARI, H., MENON, S. \& ROSENFELD, A. 2009. Global cooling: increasing world-wide urban albedos to offset CO2. Climatic Change, 94, 275-286.

BAN-WEISS, G. A., WOODS, J. \& LEVINSON, R. 2015. Using remote sensing to quantify albedo of roofs in seven California cities, Part 1: Methods. Solar Energy, 115, 777-790.

BOTHAM-MYINT, D., RECKTENWALD, G. W. \& SAILOR, D. J. 2015. Thermal footprint effect of rooftop urban cooling strategies. Urban Climate, 14, Part 2, 268-277.

BRUSE, M. 2017. ENVI-met website [Online]. Available: http://www.envimet.com [Accessed].

BRUSE, M. \& FLEER, H. 1998. Simulating surface-plant-air interactions inside urban environments with a three dimensional numerical model. Environmental Modelling \& Software, 13, 373-384.

CALENVIROSCREEN 2014. California Communities Environmental Health Screening Tool (CalEnviroScreen) 2.0. In: RODRIQUEZ, M. \& ALEXEEFF, G. V. (eds.). Office of Environmental Health Hazard Assessment.

DAN, L., BOU-ZEID, E. \& OPPENHEIMER, M. 2014. The effectiveness of cool and green roofs as urban heat island mitigation strategies. Environmental Research Letters, 9, 055002.

DAVIS, R. E., KNAPPENBERGER, P. C., MICHAELS, P. J. \& NOVICOFF, W. M. 2003. Changing heat-related mortality in the United States. Environmental Health Perspectives, 111, 1712-1718.

DEV, M. \& SURABI, M. 2011. Regional climate consequences of large-scale cool roof and photovoltaic array deployment. Environmental Research Letters, 6, 034001.

EPA 1992. Cooling our communities: a guidebook on tree planting and light-colored surfacing, U.S. Environmental Protection Agency, Office of Policy Analysis, Climate Change Division.

HART, M. \& SAILOR, D. 2009. Quantifying the influence of land-use and surface characteristics on spatial variability in the urban heat island. Theoretical and Applied Climatology, 95, 397-406.

HIRANO, Y. \& FUJITA, T. 2012. Evaluation of the impact of the urban heat island on residential and commercial energy consumption in Tokyo. Energy, 37, 371-383.

IPCC 2001. Climate Change 2001: The Scientific Basis. Chapter 2.2 How Much is the World Warming? Retrieved 2009-06-18.

KALKSTEIN, L. S., SAILOR, D. J., SHICKMAN, K., SHERIDAN, S. \& VANOS, J. 2013. Assessing the Health Impacts of Urban Heat Island Reduction Strategies in the District of Columbia. Global Cool Cities Alliance. Washington, D.C.

KOTTEK, M., GRIESER, J., BECK, C., RUDOLF, B. \& RUBEL, F. 2006. World Map of the Köppen-Geiger climate classification updated. Meteorologische Zeitschrift, 15.

MOHEGH, A., ROSADO, P., JIN, L., MILLSTEIN, D., LEVINSON, R. \& BAN-WEISS, G. 2017. Modeling the climate impacts of deploying solar reflective cool pavements in California cities. Journal of Geophysical Research: Atmospheres, 122, 6798-6817.

MORENO-GARCIA, M. C. 1994. Intensity and form of the urban heat island in barcelona. International Journal of Climatology, 14, 705-710.

NOAA. 2015. 3-Hourly NCEP North American Regional Reanalysis (NARR) Composites [Online]. Available: https://www.esrl.noaa.gov/psd/cgi-bin/data/narr/plothour.pl [Accessed].

OKE, T. R. 2002. Boundary Layer Climates, Taylor \& Francis.

PITMAN, A. J., DE NOBLET-DUCOUDRÉ, N., CRUZ, F. T., DAVIN, E. L., BONAN, G. B., BROVKIN, V., CLAUSSEN, M., DELIRE, C., GANZEVELD, L., GAYLER, V., VAN DEN HURK, B. J. J. M., LAWRENCE, P. J., VAN DER MOLEN, M. K., MÜLLER, C., REICK, C. H., SENEVIRATNE, S. I., STRENGERS, B. J. \& VOLDOIRE, A. 2009. Uncertainties in climate responses to past land cover change: First results from the LUCID intercomparison study. Geophysical Research Letters, 36, n/a-n/a. 
ROBINE, J.-M., CHEUNG, S. L. K., LE ROY, S., VAN OYEN, H., GRIFFITHS, C., MICHEL, J.-P. \& HERRMANN, F. R. 2008. Death toll exceeded 70,000 in Europe during the summer of 2003. Comptes Rendus Biologies, 331, 171-178.

SAILOR, D. J. 2002. Urban heat islands, Opportunities and challenges for mitigation and adaptation. North American Urban Heat Island Summit. Toronto, Canada.

SANTAMOURIS, M. 2007. Heat Island Research in Europe: The State of the Art. Advances in Building Energy Research, 1, 123-150.

SANTAMOURIS, M. 2014. Cooling the cities - A review of reflective and green roof mitigation technologies to fight heat island and improve comfort in urban environments. Solar Energy, 103, 682-703.

SPROUL, J., WAN, M. P., MANDEL, B. H. \& ROSENFELD, A. H. 2014. Economic comparison of white, green, and black flat roofs in the United States. Energy and Buildings, 71, 20-27.

SRIVANIT, M. \& HOKAO, K. 2013. Evaluating the cooling effects of greening for improving the outdoor thermal environment at an institutional campus in the summer. Building and Environment, 66, 158-172.

TAHA, H. 2008. Meso-urban meteorological and photochemical modeling of heat island mitigation. Atmospheric Environment, 42, 8795-8809.

TAHA, H., AKBARI, H., ROSENFELD, A. \& HUANG, J. 1988. Residential cooling loads and the urban heat island-the effects of albedo. Building and Environment, 23, 271-283.

TALEGHANI, M., SAILOR, D. \& BAN-WEISS, G. A. 2016. Micrometeorological simulations to predict the impacts of heat mitigation strategies on pedestrian thermal comfort in a Los Angeles neighborhood. Environmental Research Letters, 11, 024003.

TALEGHANI, M., SAILOR, D. J., TENPIERIK, M. \& VAN DEN DOBBELSTEEN, A. 2014a. Thermal assessment of heat mitigation strategies: The case of Portland State University, Oregon, USA. Building and Environment, 73, 138-150.

TALEGHANI, M., TENPIERIK, M. \& VAN DEN DOBBELSTEEN, A. 2014b. Indoor thermal comfort in urban courtyard block dwellings in the Netherlands. Building and Environment, 82, 566-579.

TALEGHANI, M., TENPIERIK, M., VAN DEN DOBBELSTEEN, A. \& SAILOR, D. J. 2014c. Heat in courtyards: A validated and calibrated parametric study of heat mitigation strategies for urban courtyards in the Netherlands. Solar Energy, 103, 108-124.

TALEGHANI, M., TENPIERIK, M., VAN DEN DOBBELSTEEN, A. \& SAILOR, D. J. 2014d. Heat mitigation strategies in winter and summer: Field measurements in temperate climates. Building and Environment, 81, 309-319.

UNITED STATES CENSUS BUREAU. 2010. El Monte (city) QuickFacts [Online]. Available: http://quickfacts.census.gov/qfd/states/06/0622230.html [Accessed 09.28.2015].

VAHMANI, P. \& BAN-WEISS, G. 2016. Climatic consequences of adopting drought-tolerant vegetation over Los Angeles as a response to California drought. Geophysical Research Letters, 43, 82408249.

VAHMANI, P., SUN, F., HALL, A. \& BAN-WEISS, G. 2016. Investigating the climate impacts of urbanization and the potential for cool roofs to counter future climate change in Southern California. Environmental Research Letters, 11, 124027.

ZHANG, J., ZHANG, K., LIU, J. \& BAN-WEISS, G. 2016. Revisiting the climate impacts of cool roofs around the globe using an Earth system model. Environmental Research Letters, 11, 084014. 